\title{
Contemporary Challenges for Small Open Economies
}

\author{
Ketevan Kordzadze ${ }^{1}$
}

\begin{abstract}
The paper deals with the challenges that national economies all over the world are facing with and discuss how they affect main macroeconomic indicators of national economies, how their harmful impacts can be mitigated and what the opportunities for national economies in such circumstances are. Particular attention is given to the analysis of these impacts on the economies of small developing countries with open markets which are more vulnerable to the economic and political shocks and fluctuations. Alterations of macroeconomic indicators such as GDP, foreign direct investments, unemployment rate, inflation and international trade are analyzed.

Respective data and trend analysis are given in the paper for understanding the impact that international economic and political events and processes have on the main economic indicators in the small open economy.

By signing an association agreement with the European Union Georgia becomes more integrated into the international economy that implies as opportunities as well as threats. Both of them are analyzed in the paper, possible outcomes are compared and certain recommendations are elaborated regarding the ways the country can use to obtain maximum benefits from the process of integration into the international economy.
\end{abstract}

Key words: Open economy, GDP, FDI, Unemployment, international trade.

\section{Introduction}

In 2008 global financial crisis started to destroy national economies worldwide. "The speculative new instruments, the high leverage, and the trading incentives did, for a time, generate large profits in the financial sector, but also one of the largest asset bubbles in financial history" (Magas I., 2010). When these bubbles burst the world economy stepped into deep recession.

"The recent 2008/2009 global financial crisis originating from the US seems to have induced recessions worldwide" (Taylor A., Lee J., 2014). Countries with different levels of economic development were affected in a different ways. It is particularly interesting to understand the impact of the crisis on small open economies like Georgia and how they survived in these circumstances and how these countries are being affected by economic and political turmoil happening on a global level.

In the recent decade Georgia has become highly integrated into the global economic and political processes. Hence, events occurring in international economy and policy influence economic environment in Georgia and has impact on the economic indicators of the country. In spite of huge challenges and threats coming from country's integration in the global economy, it is unquestionable that Georgia must continue its streaming to become even more integrated into global economy. But the main issue in this situation is 
that country should somehow mitigate the negative impacts on its economy coming from the global processes and find the ways of using huge opportunities for development also coming from the global processes.

In order to better understand the issue first we should define what a small open economy is. "The traditional textbook definition of a small open economy is one that is a price taker on world markets. It can import and export as much as it wants at unchanged terms of trade. Openness to capital flows likewise means an ability to borrow and lend freely at unchanged risk-adjusted world interest rates" (Wynne M. A., 2007).

It can be said that Georgia satisfies abovementioned criteria to be considered as a small open economy. Country's integration into the global economy started to deepen from 2004 when the new government came in the country and made sound reforms for liberalizing economic environment in the country and attract foreign direct investments.

In the article we would like to pay attention to two most important challenges for the global economy that are global economic and political crises.

Globalized economy provides possibilities to attract capital from foreign countries. Foreign direct investments had been increasing in Georgia with high paces till August of 2008. After the war with Russia it felt dramatically and started to increase only after two years. But it is still much less than it was before the war. One of the biggest opportunities for increasing the flow of foreign direct investments in the country is Deep and Comprehensive Free Trade Agreement with European Union. Increase of investments from EU can be stimulated due to the relatively low labor costs (compared to that of $\mathrm{EU}$ ), ease of registering business and relatively low taxes (again compared to that of EU). That in turn can stimulate to the growth of employment (Papava V., Tapladze T., 2013, pp. 6-16). Such kind of agreements represent the opportunities that globalized economy provides for countries all over the world and it is especially important for small open economies since their businesses have possibilities to increase size of the market they have access to and acquire modern methods and techniques of conducting business, increase quality of products and satisfy very demanding customers.

Table below shows the volumes of FDIs in the country for years.

Table 1. Foreign Direct Investments in Georgia Mil. USD

\begin{tabular}{|l|l|l|l|l|l|}
\hline Year & Total & Q I & Q II & Q III & Q IV \\
\hline 2005 & 449.8 & 89.4 & 105.9 & 75.6 & 178.9 \\
\hline 2006 & 1190.4 & 146.0 & 306.9 & 280.7 & 456.7 \\
\hline 2007 & 2014.8 & 421.4 & 401.5 & 489.1 & 702.9 \\
\hline 2008 & 1564.0 & 537.7 & 605.4 & 134.7 & 286.2 \\
\hline 2009 & 658.4 & 114.0 & 177.2 & 173.2 & 194.0 \\
\hline 2010 & 814.5 & 166.5 & 208.3 & 225.6 & 214.1 \\
\hline 2011 & 1117.2 & 209.7 & 248.3 & 316.6 & 342.6 \\
\hline 2012 & 911.6 & 261.2 & 217.7 & 199.0 & 233.7 \\
\hline 2013 & 941.9 & 252.3 & 207.9 & 254.8 & 226.9 \\
\hline
\end{tabular}




\begin{tabular}{|c|c|c|c|c|c|}
\hline $2014 *$ & 1272.5 & 265.3 & 150.5 & 507.5 & 349.2 \\
\hline
\end{tabular}

As it can be seen from the table FDIs in the country didn't return to the level of 2007. In this case both economic and political factors affected significantly on the reduction of FDIs. For the developing countries growing foreign direct investments are essential to ensure sustainable development. During the hard economic times investments made all over the world decrease and that is particularly harmful for small open economies without insufficient internal capital and dependent on foreign capital.

In such circumstances it is essential to provide foreign investors with stable economic and political environment, low taxes, liberalized economy and relatively cheap but qualified labor force in order to give them incentives for investing in the country.

Another challenge for small open economy is the competitiveness of its industries. In Georgia for example small agricultural households aren't competitive on the market compared to foreign importers who provide relatively cheap products on the market. In such circumstances many agricultural households think about leaving their business in the villages and move to the big cities to find the job. That in turn contributes to the inefficiencies in the labor allocation and increases unemployment in the country. Many governments (not only governments of countries with small open economies) support such vulnerable sectors of their economy and the government support to small business (including agricultural households) should be considered as a way of mitigating the influence that big importer companies have on the market.

Georgia's economy is highly dependent on the remittances from the people working outside the country. During the global economic crisis these remittances decreased considerably and the money spent on the consumption within the country also decreased. It should be mentioned that huge amount of remittances in Georgia comes from Greece and Italy (second and third places after Russia respectively). These are the countries that were very seriously affected by the global economic crisis and hence the remittances from these countries decreased. The most difficult years were 2009 and 2010. After these years situation started to improve.

In 2011 remittances to Georgia amounted \$812.6 million and accounted 6\% of GDP (Economic policy research center, 2012). It is very important share of Georgia's economy and it can be concluded that country's GDP was affected by the economic crisis in this regard.

After the war and global economic crisis many construction companies became bankrupts and the high paces of the development of construction sector was hampered. 
Table 2. Construction sector facts

\begin{tabular}{|l|l|l|l|l|l|l|l|l|l|l|}
\hline & 2004 & 2005 & 2006 & 2007 & 2008 & 2009 & 2010 & 2011 & 2012 & 2013 \\
\hline Turnover, mil GEL & 387.4 & 778.8 & 1125.3 & 1604.6 & 1412.0 & 1736.3 & 1694.5 & 3348.0 & 4444.7 & 3244.7 \\
\hline Production value, mil GEL & 383.7 & 768.9 & 1186.0 & 1718.2 & 1434.7 & 1752.6 & 1728.5 & 3371.5 & 4596.7 & 3554.4 \\
\hline Value added,mil GEL & 127.1 & 246.0 & 401.4 & 630.6 & 482.3 & 605.2 & 618.1 & 1178.5 & 1657.2 & 1594.7 \\
\hline Intermediate consumption,mil GEL & 256.5 & 523.0 & 784.5 & 1087.6 & 952.4 & 1147.5 & 1110.4 & 2192.9 & 2939.5 & 1959.8 \\
\hline Fixed assets,mil GEL & 127.2 & 258.7 & 474.9 & 635.1 & 652.2 & 723.8 & 799.1 & 518.0 & 1898.7 & 1397.8 \\
\hline Number of employed, persons & 21344 & 38560 & 46681 & 52572 & 38109 & 43452 & 40303 & 65220 & 69946 & 65863 \\
\hline $\begin{array}{l}\text { Average monthly remuneration } \\
\text { employed persons, GEL }\end{array}$ & 237.9 & 292.3 & 391.0 & 495.1 & 600.9 & 629.0 & 674.6 & 741.3 & 893.2 & 869.9 \\
\hline
\end{tabular}

Source: National Statistics Office of Georgia

Construction sector accounts almost 10\% in Georgia's GDP and during the first year of the crisis reduction in the sector contributed to the significant reduction in Georgia's GDP.

In the first years of the global financial crisis growth rates of Georgia's GDP was very low since the situation was worsened by the military conflict with Russia.

Table 3. Gross Domestic Product (GDP)

\begin{tabular}{|l|l|l|l|l|l|l|l|l|l|}
\hline & 2008 & 2009 & 2010 & 2011 & 2012 & 2013 & I 14 & II 14 & III 14 \\
\hline $\begin{array}{l}\text { GDP at current prices, } \\
\text { mil. GEL }\end{array}$ & 19074.9 & 17986.0 & 20743.4 & 24344.0 & 26167.3 & 26847.4 & 6307.2 & 7162.8 & 7540.1 \\
\hline $\begin{array}{l}\text { GDP at constant 2003 } \\
\text { prices, mil. GEL }\end{array}$ & 12555.3 & 12085.5 & 1235.0 & 13757.2 & 14637.7 & 15123.7 & 3504.1 & 3919.4 & 4102.2 \\
\hline $\begin{array}{l}\text { GDP real growth, } \\
\text { percent }\end{array}$ & 2.6 & -3.7 & 6.2 & 7.2 & 6.4 & 3.3 & 7.2 & 5.2 & 5.6 \\
\hline $\begin{array}{l}\text { GDP deflator, percent } \\
\text { GDP per capita (at }\end{array}$ & 9.4 & -2.0 & 8.6 & 9.5 & 1.0 & -0.7 & 1.9 & 4.0 & 4.5 \\
\hline $\begin{array}{l}\text { GDP } \\
\text { current prices), GEL }\end{array}$ & 4101.3 & 4675.7 & 5447.1 & 5818.1 & 5987.6 & 1404.6 & 1595.1 & 1679.1 \\
\hline $\begin{array}{l}\text { GDP per capita (at } \\
\text { current prices), USD }\end{array}$ & 2921.1 & 2455.2 & 2623.0 & 3230.7 & 3523.4 & 3599.6 & 802.9 & 905.0 & 962.1 \\
\hline $\begin{array}{l}\text { GDP at current prices, } \\
\text { mil. USD }\end{array}$ & 12800.5 & 10767.1 & 11636.5 & 14438.5 & 15846.8 & 16139.9 & 3605.3 & 4064.1 & 4320.4 \\
\hline
\end{tabular}

Source: National Statistics Office of Georgia

Another case of the impact of political crisis on the country's economy was the embargo imposed by Russian government on Georgian products. Since very significant share of Georgia's export came on the Russian market country's economy were affected severely. 
The biggest problems were created in the vine sector, because Russia was main export destination of Georgian wine. Russia remained Georgia's largest foreign market for wine exports until the embargo. Share of Russian market in Georgia's wine export was about $80 \%$.

Graph 1. Georgian wine export by years (thousands USD)

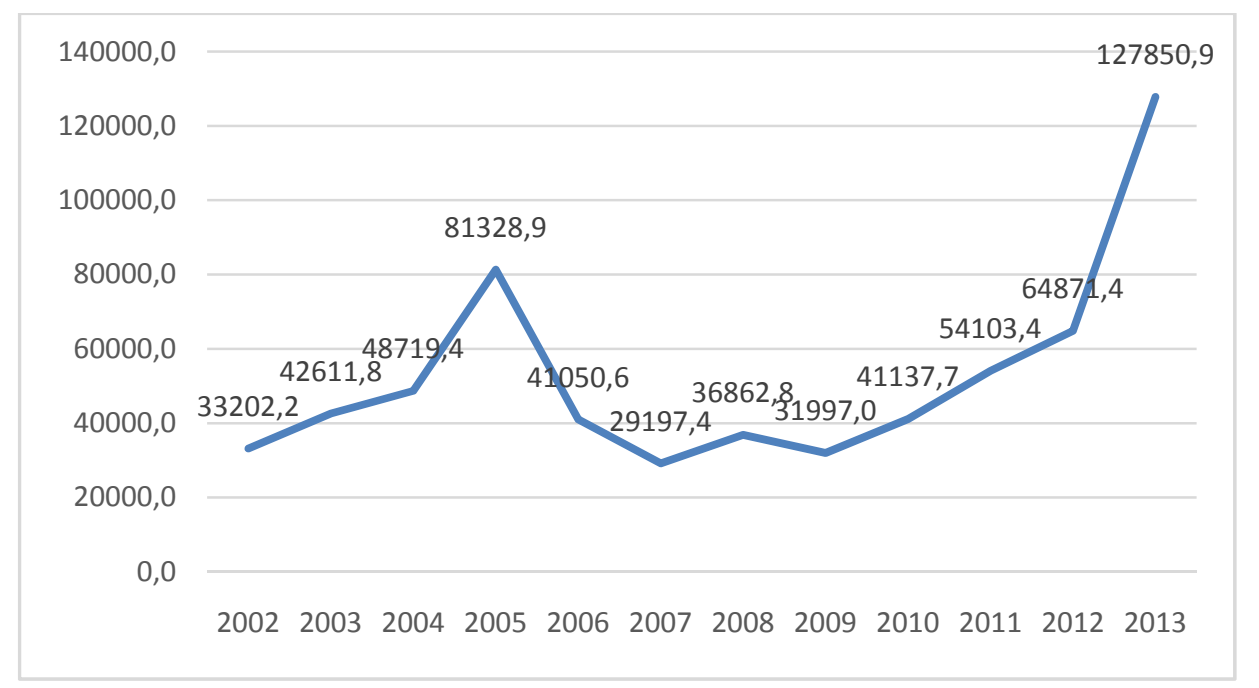

Source: National Statistics Office of Georgia

This is a clear example how international political events can affect small open economy. Russia was one of the main trade partners for Georgia and blocking its market for Georgian products significantly reduced Georgia's export of products.

But despite this case globalization of world's economy provides huge opportunities for trade especially bilateral or regional agreements should be mentioned that provide opportunities for trade with favorable conditions for each side.

Another important issue is inflation. Since Georgia is import dependent country any increases in product prices on international markets are reflected in Georgia's market and contributes to price increase. In order to avoid such adverse impacts of changes in world prices it is necessary to increase national production and replace significant part of imported products with products made domestically.

"It can be argued that small economies have both advantages and disadvantages, in particular disadvantages relating to economies of scale, less diversification and macroeconomic policy autonomy, but also - at least potential - sociological and political advantages in achieving greater social cohesion. The latter is important because these factors are generally recognised as important determinants of the investment climate and economic growth" (Ocampo J. A., 2002). 


\section{Conclusion}

In conclusion it can be said that small open economies are very vulnerable to economic and political shocks and these unfavorable impacts are very immediate. In the case of Georgia we can say that country needed 2-3 years to regain economic stability and improve economic indicators.

Here some recommendations can be elaborated for avoiding or mitigating negative impacts from economic and political shocks on an international level.

First, it is of utmost importance to provide sustainable growth of industries in the country and increase its production capacity. That is necessary to reduce dependence on imported products. Increased levels of national production will create additional jobs and make country's economy more independent.

Second, country's economic environment should be highly attractive for investors and political stability should be ensured in order to create solid incentives for foreign investors to invest in the country even in the hard economic times in the world.

Third, small open economy should invest much in research and development in order to have highly qualified workforce in the country that is very important incentive for foreign investors to invest in various sectors of country's economy.

\section{References}

Economic policy research center, Role of international remittances in Georgia's economy, press release, 2012;

Magas I., Impacts of the financial crisis on a small open economy: the case of Hungary;

National Statistics Office of Georgia;

Ocampo J. A., Small Economies in the Face of Globalisation, Third William G. Demas Memorial Lecture at the Caribbean Development Bank, Cayman Islands, 14 May, 2002;

Papava V., Tapladze T., On the main trends and prospects of the Georgia's economic development", Journal "Ekonomisti", \#2, 2013, pp. 6-16;

Taylor A., Lee J., The Propagation of the US Financial Crisis to a Small Open Economy: Evidence from Korea, Korea and the World Economy, Vol. 15, No. 1 (April 2014) 87-96;

Wynne M. A., How have small open economies responded to the challenge of globalization?, Federal Reserve Bank of Dallas, Research Department, Bank of Iceland conference on "The Challenges of Globalization for Small Open Economies with Independent Currencies", Reykjavik, Iceland, May 31 - June 1, 2007. 